Transcontinentales

continentales

Sociétés, idéologies, système mondial

Afrique plurielle

\title{
Asie du Sud-Est
}

\section{(2) OpenEdition \\ 12 Journals}

Édition électronique

URL : http://journals.openedition.org/transcontinentales/1494

DOI : 10.4000/transcontinentales. 1494

ISBN : 978-2-8218-1408-0

ISSN : 1775-397X

\section{Éditeur}

Editions de la maison des sciences de l'homme

\section{Édition imprimée}

Date de publication : 30 juin 2006

Pagination : 188

ISBN : 2200-92169-1

ISSN : $1950-1684$

\section{Référence électronique}

"Asie du Sud-Est », Transcontinentales [En ligne], 2 | 2006, document 29, mis en ligne le 15 décembre 2012, consulté le 25 septembre 2020. URL : http://journals.openedition.org/transcontinentales/1494 ; DOI : https://doi.org/10.4000/transcontinentales.1494

Ce document a été généré automatiquement le 25 septembre 2020.

Tous droits réservés 


\section{Asie du Sud-Est}

RochigneuX Grégoire (dir.), Cambodge soir. Chroniques sociales d'un pays au quotidien, Bangkok, IRASEC/Éditions du Mékong Éditions aux lieux d'être, 2005, 222 p. 